\title{
PERSEPSI MAHASISWA TERHADAP FUNGSI PANCASILA SEBAGAI WELTANSCHAUUNG DALAM UPAYA MENGATASI MEROSOTNYA NILAI KEBANGSAAN \\ Ilham Syahrul Jiwandono ${ }^{1}$, Iswahyu Nurbeni ${ }^{2}$ \\ ${ }^{1)}$ PGSD Universitas Mataram, ${ }^{2)}$ SDN 1 Banjarejo \\ E-mail: ${ }^{1)}$ ilham_jiwandono@unram.ac.id \\ 2) arulia22@gmail.com
}

\begin{abstract}
Abstrak: Beberapa tahun terakhir eksistensi Pancasila dalam fungsinya sebagai dasar negara (philophische grondslag) dan pandangan hidup bangsa (weltanschauung) dipertaruhkan. Banyak tantangan dan rintangan yang dihadapi oleh Pancasila dalam mempertahankan eksistensinya. Kemerosotan nilai-nilai bangsa menjadi tantangan tersendiri yang dihadapi oleh Pancasila. Terorisme, radikalisme, narkoba, korupsi, hilangnya toleransi serta melunturnya rasa nasionalisme dan patriotisme sudah menjadi bukti merosotnya nilai-nilai kebangsaan. Mahasiswa sebagai agent of change harus peka dalam melihat situasi ini dan diharapkan mempunyai solusi dalam memecahkan masalah merosotnya nilai-nilai kebangsaan. Penelitian ini bertujuan untuk mengetahui persepsi mahasiswa terhadap fungsi Pancasila sebagai weltanschauung dalam upaya menghadapi merosotnya nilai-nilai kebangsaan. Lokasi penelitian di Program Studi Pendidikan Guru Sekolah Dasar Universitas Mataram. Pendekatan penelitian menggunakan kualitatif deskriptif. Metode pengumpulan data menggunakan wawancara, observasi dan dokumentasi. Analisis data menggunakan pengumpulan data, reduksi data, penyajian data dan penarikan kesimpulan. Tahap penelitian melalui tahap perencanaan dan pelaksanaan. Hasil penelitian menunjukkan bahwa: 1) mayoritas mahasiswa masih percaya bahwa Pancasila sebagai weltanschauung masih mampu menghadapi berbagai persoalan tentang merosotnya nilai-nilai kebangsaan, 2) diperlukan penanaman nilai-nilai pancasila melalui pendekatan multiapproach, multimedia, multidiscipline dan multistake holders dalam kehidupan sehari-hari.
\end{abstract}

Kata kunci: Pancasila, Philosopische Grondslag, Weltanschauung, NilaiNilai Bangsa

Abstract: The last few years of the existence of Pancasila in its function as the basic of the state (philophische grondslag) and the way of life (weltanschauung) were at stake. Terrorism, radicalism, drugs, corruption, loss of tolerance and the weakening of the sense of nationalism and patriotism have been proof of the decline of national values. Students as agents of change must be sensitive in seeing this situation and expected to have a solution in solving the problem of declining national values. This study aims to determine students' perceptions the function of Pancasila as a weltanschauung in an effort to deal with the decline of national values. The research location in the Universty of Mataram, Elementary School Teacher Education Study Program. The research approach uses descriptive qualitative. Methods of data collection using interviews, observation and documentation. Data analysis using data collection, data reduction, data presentation and conclusion. Research phase through the planning and implementation stages. The results of the study show that: 1) the majority of students still believe that the Pancasila as a weltanschauung is still able to face various problems regarding the decline of national values, 2 ) it is necessary to cultivate the values of the Pancasila through a multimedia, multidiscipline and multistakeholder approach in daily life.

Keywords: Pancasila, Philosopische Grondslag, Weltanschauung, National Values 


\section{ELSE (Elementary School Education Journal) \\ Volume 3 Nomor 2 Agustus 2019 \\ P-ISSN: 2581-1800 E-ISSN: 2597-4122 \\ Email: else@um-surabaya.ac.id}

\section{PENDAHULUAN}

Pancasila sebagai dasar filsafat negara (philosophische grondslag) dan pandangan hidup bangsa (Weltanschauung) merupakan kesepakatan para founding fathers negara. Pancasila sebagai dasar filsafat negara (Philosophische Grondslag)berartinilai-nilai filosofis yang terkandung dalam sila-sila Pancasila mendasari seluruh peraturan hukum yang berlaku di Indonesia. Artinya, nilai ketuhanan, kemanusiaan, persatuan, kerakyatan dan keadilan harus mendasari seluruh peraturan perundang-undangan yang berlaku (Syarbaini, 2012: 144). Sedangkan Pancasila sebagai Weltanschauung, artinya nilai-nilai Pancasila itu merupakan sesuatu yang telah ada dan berkembang di dalam masyarakat Indonesia yang kemudian disepakati sebagai dasar filsafat negara (Philosophische Grondslag). Weltanschauung merupakan sebuah pandangan dunia (world-view). Ajaran tentang nilai, makna, dan tujuan hidup manusia yang terpatri dalam Weltanschauung itu menyebar dalam berbagai pemikiran dan kebudayaan Bangsa Indonesia (Syarbaini, 2012: 145).

Pancasila sebagai Weltanschauung berarti nilai-nilai pancasila merupakan etika kehidupan bersama bangsa Indonesia. Nilai-nilai tersebut atau praksis kehidupan di dalam masyarakat bangsa Indonesia diatur oleh nilai-nilai pencasila. Dengan kata lain setiap anggota masyarakat Indonesia mewujudkan di dalam kehidupan sehati-harinya nilai-nlai pancasila seperti di dalam kegiatan berketuhanan yang maha esa yang meminta toleransi serta menghargai sesama yang berbeda keyakinan agamanya.

Diterimanya Pancasila sebagai dasar negara dan pandangan hidup bangsa membawa konsekuensi logis bahwa nilai-nilai Pancasila harus selalu dijadikan landasan pokok serta landasan fundamental bagi pengaturan serta penyelengggaraan negara. Pengakuan Pancasila sebagai pandangan hidup bangsa mengharuskan kita sebagai bangsa untuk mentransformasikan nilai-nilai Pancasilai itu ke dalam sikap dan perilaku nyata baik dalam kehidupan bermasyarakat, berbangsa dan bernegara.Namun, dalam perjalanan sebagai Weltanschauung, Pancasila menghadapi berbagai tantangan dalam upaya mempertahankan eksistensi dan konsistensinya. Bahkan Moerdiono (1996: 15) menegaskan bahwa tantangan terbesar bagi suatu ideologi adalah menjaga konsistensi antara nilai dasar, nilai instrumental dan nilai praksisnya. Sudah barang tentu jika konsistensi ketiga nilai itu dapat ditegakkan, maka terhadap ideologi itu tidak akan ada masalah. Tantangan nyata yang dihadapi Pancasila saat ini adalah merosotnya nilai-nilai kebangsaan. Kita merasakan krisis 


\section{ELSE (Elementary Schod Education Journal) \\ Volume 3 Nomor 2 Agustus 2019 \\ P-ISSN: 2581-1800 E-ISSN: 2597-4122 \\ Email:else@um-surabaya.ac.id}

multidimensi diberbagai bidang. Nilai keakraban bangsa menjadi luntur, nilai-nilai agama dan budaya terasa kurang diperhatikan atau dipahami secara sempit dan dangkal, toleransi rendah, radikalisme, terorisme serta rasa nasionalisme dan patriotisme yang semakin merosot.

Dari observasi awal yang telah dilakukan di lokasi penelitian menunjukkan adanya indikasi-indikasi kemerosotan nilai-nilai kebangsaan seperti yang disebutkan diatas. Dalam keadaan seperti ini sering tampak perilaku masyarakat menjadi lebih liar bagi yang punya kesempatan. Sebagian masyarakat tampak beringas dan mendemostrasikan sikap antisosial, antikemapanan dan tidak produktif serta goyah dalam keseimbangan rasio dan emosinya (Yudistira, 2016). Perilaku negatif yang lain yaitu mudahnya terpengaruh oleh ajaran-ajaran agama yang ditafsirkan sempit padahal agama tidak ada yang mengajarkan kekerasan. Mahasiswa sebagai kaum yang terpelajar harus peka melihat situasi ini. Mereka harus mampu menjadi pionir dalam menghadapi persoalan itu dengan cara mengembangkan nilainilai yang terkandung dalam Pancasila di berbagai bidang kehidupan, termasuk di bidang pendidikan. Hal itu penting dilakukan mengingatPancasila sebagai Weltanschauungsaat ini semakin kabur dalam segala tatanan kehidupan yang mengarah kepada liberalism menyebabkan nilai-nilai Pancasila yang merupakan nilai dasar dalam kehidupan berbangsa dan bernegara semakin di tinggalkan. Padahal, Pancasila sebagai dasar negara dan pandangan hidup bangsa Indonesia telah menyelamatkan bangsa Indonesia dari ancaman disintegrasi selama lebih dari tujuh puluh tahun. Oleh karena itu peran Pancasila dalam kehidupan sehari-hari baik di lingkungan sekolah maupun masyarakat sangat dibutuhkan dalam rangka mengembalikan nilai-nilai kebangsaan yang semakin memudar.

\section{METODE PENELITIAN}

Penelitian ini menggunakan metode deskriptif kualitatif. Metode deskriptif kualitatif sebagaimana dikemukakan oleh Nawawi (2012: 67) dapat diartikan sebagai prosedur pemecahan masalah yang diselidiki dengan menggambarkan atau melukiskan keadaan subyek/obyek kajian pada saat sekarang berdasarkan fakta-fakta yang tampak, atau sebagaimana adanya. Subyek dalam penelitian ini adalah mahasiswa Program Studi

Pendidikan Sekolah Dasar Universitas mataram. Lokasi penelitian di Program Studi Pendidikan Guru Sekolah Dasar Universitas Mataram. 


\section{ELSE (Elementary School Education Journal) \\ Volume 3 Nomor 2 Agustus 2019 \\ P-ISSN: 2581-1800 E-ISSN: 2597-4122 \\ Email: else@um-surabaya.ac.id}

Metode pengumpulan data melalui observasi, wawancara dan dokumentasi. Sedangkan analisis data menggunakan pengumpulan data, reduksi data, penyajian data dan penarikan kesimpulan. Tahap-tahap dalam penelitian ini meliputi tahap perencanaan yang meliputi (1) mengurus perizinan, (2) menyusun skenario penelitian, (3) merancang pedoman wawancara. Sedangkan tahap yang kedua adalah tahap pelaksanaan yang meliputi: (1) observasi, (2) pengumpulan data, (3) konfirmasi data, (4) analisis data, dan (5) pembuatan laporan penelitian. Teknik analisis data yang digunakan adalah teknik analisis data deskriptif kualitatif memanfaatkan persentase hanya merupakan langkah awal dari proses analisis data (Arikunto, 2000: 352).

\section{HASIL DAN PEMBAHASAN}

\section{Pancasila Sebagai Weltanschauung}

Pancasila adalah ideologi atau pandangan hidup (weltanschauung) bangsa indonesia. Pancasila lahir dari hasil galian para pendiri bangsa atau sering kita sebut sebagai the founding father. Ia diambil dari budaya Indonesia sendiri. Pancasila menjadi miniatur karakter kepribadian yang dimiliki oleh bangsa Indonesia. Pancasila dijadikan pegangan dalam kehidupan sehari-hari. Hal ini sesuai dengan pendapatSastrapratedja (2001:1) yang mengatakan bahwa Pancasila adalah dasar politik yang mengatur dan mengarahkan segala kegiatan yang berkaitan dengan hidup kenegaraan, seperti perundang undangan, pemerintahan, perekonomian nasional, hidup berbangsa, hubungan warga negara dengan negara, dan hubungan antarsesama warga negara, serta usaha-usaha untuk menciptakankesejateraan bersama. Oleh karena itu, Pancasila harus menjadi operasional dalam penentuan kebijakan kebijakan dalam bidang-bidang tersebut di atas dan dalam memecahkan persoalan persoalan yang dihadapi bangsa dan negara. Dari hasil wawancara, observasi dan dokumentasi yang telah dilakukan diperoleh informasi bahwa selama ini banyak mahasiswa yang sudah mengamalkan nilai-nilai Pancasila dalam kehidupan seharihari, baik di bidang politik, pendidikan maupun hubungan antar sesama.Namun mereka juga menggarisbawahi bahwa PR pemerintah masih banyak, utamanya dalam hal penegakan HAM dam hukum. Mahasiswa menyoroti kasus penyiraman air keras yang dilakukan kepada Novel Baswedan yang hingga kini masih belum terselesaikan.Hal ini juga diperkuat oleh hasil statistik yang dilakukan oleh Setara Indonesia yang diberitakan oleh Tirto (2018). 


\section{ELSE (Elementary Schoul Education Journal) \\ Volume 3 Nomor 2 Agustus 2019 \\ P-ISSN: 2581-1800 E-ISSN: 2597-4122 \\ Email:else@um-surabaya.ac.id}

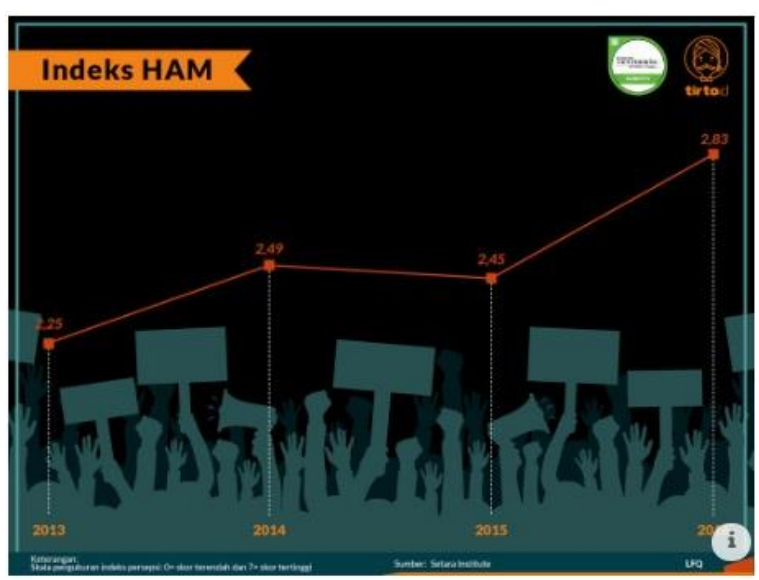

Gambar 1. Indeks Kinerja HAM

Berdasarkan data indeks kinerja HAM diatas menunjukkan peningkatan sejak 2014 hingga 2016; pada 2014 skor indeks sebesar 2,25 dan naik menjadi 2,83 pada 2016 (skor tertinggi 7). Namun, peningkatan tersebut tidak signifikan lantaran kenaikannya hanya sebesar 0,58 dalam rentang tiga tahun. Selain itu, skor 2 pada indeks menunjukkan bahwa performa kinerja HAM Indonesia masih sangat rendah. Dari data diatas dapat ditarik kesimpulan bahwa permasalahan HAM masih menjadi tugas berat bagi pemerintah.

\section{Faktor Penyebab Lunturnya Nilai-Nilai Kebangsaan}

Berdasarkan hasil wawancara dengan mahasiswa Program Studi Pendidikan Guru Sekolah Dasar, dapat diperoleh informasi mengenai penyebab mengapa saat ini nilai-nilai kebangsaan yang dimilik oleh Indonesia merosot, diantaranya adalah sebagai berikut (1) kurang efektifnya penanaman nilai-nilai Pancasila dalam kehidupan sehari-hari. Selama ini, penanaman nilai-nilai Pancasila hanya sebatas diajarkan melalui Pendidikan Pancasila dan Kewarganegaraan saja. (2) belum adanya dukungan secara penuh dari pemerintah. Penguatan nilai-nilai Pancasila melalui program Penguatan Pendidikan Karakter (PPK) selama ini lebih banyak menyasar sekolah yang berada di perkotaan, sedangkan sekolah yang berada di pedesaat masih banyak yang belum tersentuh program tersebut. (3) kurangnya pemahaman terhadap agama. Selama ini agama hanya dijadikan sebagai identitas saja sehingga pemahaman terhadap agama tersebut sangat kurang. Agama hanya dijadikan alat untuk mencapai kepentingan tertentu. Akibatnya adalah banyak terjadi kasus terorisme dan radikalisme yang notabene akibat dari kurangnya pemahaman terhadap agama. (4) lingkungan pergaulan yang berubah. Seiring dengan pesatnya arus globalisasi serta beragam budaya yang dibawanya secara tidak langsung memengaruhi pergaulan 


\section{ELSE (Elementary School Education Journal) \\ Volume 3 Nomor 2 Agustus 2019}

P-ISSN: 2581-1800 E-ISSN: 2597-4122

Email: else@um-surabaya.ac.id

masyarakat yang bertentangan dengan nilai-nilai Pancasila. (5) euphoria reformasi yang berlebihan. Banyak masyarakat yang merasa bebas seolah-olah keluar dari belenggu setelah adanya reformasi. Banyak ujaran kebencian yang dicuitkan di berbagai media seakan-akan mereka punya hak yang tidak ada batasnya. Hal ini jelas mengancam persatuan dan kesatuan bangsa. Mereka lupa bahwa negara Indonesa adalah negara hukum. Segala sesuatu yang dilakukan dan bertentangan dengan hukum pasti akan berhadapan dengan hukum.

\section{Solusi mengembalikan nilai-nilai kebangsaan.}

Pancasila dapat dikatakan sebagai lima nilai fundamental yang diidealisasikan sebagai konsepsi tentang dasar falsafah negara (philosophische grondslag), pandangan hidup dan ideologi negara (weltanschauung) Indonesia. Setelah lebih dari 70 tahun ditahbiskan sebagai dasar falsafah negara dan ideologi negara, apakah kesaktiannya masih bisa diandalkan di tengah arus globalisasi dengan penetrasi beragam ideologi yang memboncengnya? Secara konseptual, Pancasila merupakan ideologi tahan banting yang kian relevan dengan perkembangan zaman. Namun secara operasional, terdapat jurang yang kian lebar antara idealitas Pancasila dan realitas pembumian dan pembudayaannya. Secara garis besar, terdapat beberapa cara pembumian Pancasila dalam jenjang pendidikan sekolah dasar, yakni dengan melibatkan pendekatan multi-approaches, multi-disciplines, multimedia, multi-platforms dan multi-stake holders. Berdasar wawancara dengan mahasiswa, diperlukan berbagai pendekatan dalam proses pembelajaran di kelas. Pertama, selama ini mahasiswa merasa proses pembelajaran di kelas hanya menggunakan pendekatan behaviorisme di kelas, tanpa menggunakan pendekatan lain, misalkan konstruktivisme.

Kedua, menurut mereka, diperlukan kolaborasi berbagai mata pelajaran dalam upaya mengembalikan nilai-nilai kebangsaan. Mereka menganggap selama ini yang bertanggung jawab membina karakter adalah mata pelajaran PPKn semata. Ketiga, pemanfaatan bernagai media dalam proses pembelajaran di kelas. Mereka menganggap selama ini guru maupun dosen hanya menggunakan media video dan gambar. Padahal, banyak media yang bisa dipakai dalam rangka menumbuhkan nilai-nilai kebangsaan. Keempat, penggunaan berbagai teknologi sangat diperlukan. Dengan kemajuan teknologi seperti saat ini, penting rasanya memanfaatkan teknologi itu dalam mengembangkan 


\section{ELSE (Elementary School Education Journal) \\ Volume 3 Nomor 2 Agustus 2019 \\ P-ISSN: 2581-1800 E-ISSN: 2597-4122 \\ Email:else@um-surabaya.ac.id}

karakter masyarakat Indonesia. Mereka berpendapat menggunakan video blog (Vlog) sangat efektif dalam mengenalkan nilai-nilai kebangsaan. Selain itu, menggunakan twitter, facebook, Instagram maupun platform lain sangat berguna mengingat banyak generasi muda yang familiar dengan platform tersebut.

Kelima, mereka berpendapat bahwa menumbuhkan nilai-nilai kebangsaan bukan hanya tugas guru dan dosen semata, melainkan juga pemangku kepentingan yang lain, misalkan kepala dinas pendidikan hingga tingkat menteri. Mahasiswa pendidikan guru sekolah dasar sebagai calon guru mengeluh tentang ini seolah-olah yang bertanggung jawab dalam membentuk dan mengembangkan nilai-nilai kebangsaan adalah tugas mereka semata. Keenam, meningkatkan kualitas kepimpinan yang selama ini banyak dikeluhkan oleh berbagai pihak. Hal ini sesuai dengan pendapat Santoso (2008:6) yang mengatakan bahwa solusi untuk mengembalikan nilai-nilai kebangsaan yang merosot yaitu pertama, meningkatkankualitas kepemimpinan. Kedua, merevitalisasimereaktualisasi nasionalisme. Ketiga, meningkatkan militansi bangsa. Keempat, meneguhkan jati diribangsa sesuai dengan nilai-nilai luhur bangsa.

\section{KESIMPULAN DAN SARAN}

Pancasila sebagai dasar filsafat negara dan pandangan hidup bangsa selama ini dirasa mampu untuk mengatasi berbagai kemerosotan nilai-nilai bangsa. Tanpa adanya Pancasila, mustahil rasanya selama lebih dari 70 tahun ini negara kesatuan republic Indonesia masih kokoh berdiri. Hal ini membuktikan bahwa Pancasila merupakan resep dalam menghadapi persoalan yang menimpa bangsa Indonesia. Ada beberapa penyebab mengapa nilai-nilai kebangsaan Indonesia merosot, diantaranya adalah kurang efektifnya cara menanamkan nilai-nilai Pancasila dan kurangnya pemahaman terhadap nilai agama.

Beberapa solusi dalam mengatasi permasalahan tersebut adalah menggunakan pendekatan multiapproaches, multimedia, multidiscipline, multiplatform dan multistake holders. Diperlukan komitmen dari berbagai pihak dalam upaya mengembangkan nilainilai kebangsaan. 


\section{ELSE (Elementary Schuol Education Journal) \\ Volume 3 Nomor 2 Agustus 2019 \\ P-ISSN: 2581-1800 E-ISSN: 2597-4122 \\ Email: else@um-surabaya.ac.id}

\section{DAFTAR PUSTAKA}

Arikunto, Suharsimi. 2009. Prosedur Kajian Suatu Pendekatan Praktik. Jakarta: Rineka Cipta.

Gerintya, Scholastika. 2018. Catatan Suram Janji PenegakanHAM. [internet]. [cited 10 Juli 2019]. Available from: https://tirto.id/dbFm,

Moerdiono, P.S. 1996.Pancasila Sebagai Ideologi. Jakarta: BP-7 Pusat.

Nawawi, Hadari. 2012. Metode Kajian Bidang Sosial. Yogyakarta: Gadjah Mada University Press.

Santoso, DJ. 2008. Ketahanan Negara dan Wawasan Kebangsaan dalam Menghadapi Tantangan Global. Makalah Disampaikan Pada Symposium Nasional Peringatan Satu Abad Kebangkitan Nasional. Yogyakarta : UGM.

Sumadi, Sastradipradja. 1995. Pancasila Sebagai Pandangan Hidup Bangsa Indonesia. Jakarta : Ghalia Indonesia.

Syarbaini, Syahrial. 2012. Pendidikan Pancasila di Perguruan Tinggi. Implementasi NilaiNilai Karakter Bangsa. Jakarta : Ghalia Indonesia.

Yudistira. 2016. Seminar Nasional Hukum Volume 2 Nomor 1 Tahun 2016, 421-436. 